\title{
SISTEM PEDUKUNG KEPUTUSAN MENENTUKAN TINGKAT KUALITAS KESEJAHTERAAN MASYARAKAT BERDASARKAN INDIKATOR BADAN KOORDINASI KELUARGA BERENCANA NASIONAL MENGGUNAKAN WEB MOBILE (STUDI KASUS DESA KUTAWARINGIN)
}

\author{
Abdul Hamid1, Muhamad Muslihudin2,* \\ STMIK Pringsewu Lampung, Jl. Wisma Rini No. 09 pringsewu Lampung website: www.stmikpringsewu.ac.id \\ (coresponding author) muslih.udin@ymail.com*
}

\begin{abstract}
To determine the quality level of the village community welfare Kutawaringin to do a survey using a web-based Decision Support System with indicators that have been set by the National Family Planning Coordinating Board. The method used in the data collection phase is observation, interview and library and uses the method waterfall in the systems development process. The system contains the index page, the page appears, login page, and the page questionnaires. The system is designed with PHP as the programming language connection database, MySQL as the database, Macromedia Dreamweaver for web design, $J$ query Mobile Framework for mobile and web design as the Apache web server. Implementation of the system is designed using prototyping models. Web-based Decision Support System can help community welfare quality assessment quickly. By using the data of 800 residents in the survey showed 43 people were classified underprivileged, 120 people prosperous 1, 259 people prosperous 2, 324 people and 54 people prosperous 33 plus relatively prosperous.
\end{abstract}

Keyword- DSS, Welfare Indicators, BKKBN, Kutawaringin

Intisari - Untuk menentukan tingkat kualitas kesejahteraan masyarakat Desa Kutawaringin dapat dilakukan survey menggunakan Sistem Penunjang Keputusan berbasis web dengan indikator yang telah di tetapkan oleh Badan Koordinasi Keluarga Berencana Nasional. Metode penelitian yang digunakan dalam tahap pengumpulan data adalah observasi, wawancara dan pustaka dan menggunakan metode waterfall dalam proses pengembangan sistem. Sistem berisi tentang halaman index, halaman tampil, halaman login, dan halaman quisioner. Sistem dirancang dengan PHP sebagai bahasa pemrograman pengkoneksi database, MySQL sebagai database, Macromedia Dreamweaver untuk perancangan web, Jquery Mobile Framework untuk perancangan web mobile dan Apache sebagai server web. Implementasi sistem yang di rancang menggunakan model prototyping. Sistem Penunjang Keputusan berbasis web dapat membantu penilaian kualitas kesejahteraan masyarakat dengan cepat. Dengan menggunakan 800 data penduduk yang di survai didapatkan hasil 43 orang digolongkan prasejahtera, 120 orang sejahtera 1, 259 orang sejahtera 2, 324 orang sejahtera 3 dan 54 orang tergolong sejahtera 3 plus.

Kata Kunci : SPK, Kesejahteraan, Indikator, BKKBN, Kutawaringin

\section{PENDAHULUAN}

A. Latar Belakang Masalah

Kesejahteraan masyarakat merupakan salah satu tujuan yang ingin dicapai ketika sebuah organisasi pemerintahan di bentuk. Pemerintah harus selalu mengevaluasi tingkat kesejahteraan masyarakat yang berada di wilayah kekuasaannya sebagai bahan penunjang keputusan penetapan kebijakan-kebijakan perekonomian salah satu caranya dengan melakukan survei. Survei dapat di lakukan dengan menggunakan kriteria penilaian yang telah di tetapkan oleh lembaga negara yaitu Badan Pusat Statistik (BPS) dan Badan Koordinasi Keluarga Berencana Nasional (BKKBN).

Desa Kutawaringin resmi berdiri pada tahun 2013 merupakan hasil pemekaran dari desa Bandungbaru dan terletak di Kecamatan Adiluwih Kabupaten Pringsewu Provinsi Lampung. Dalam data Rencana Kerja Pembangunan Pekon (RKPP) Tahun Anggaran 2013 tertulis total ada 802 kepala keluarga dan jumlah total penduduk 3.033 orang dengan perincian total penduduk laki-laki 1590 orang dan penduduk perempuan 1411 orang. 
Dalam upaya mengetahui tingkat kesejahteraan warga Desa Kutawaringin, perlu di lakukan survei kepada setiap keluarga untuk mendapatkan data yang akurat. Proses survei dan perhitungan hasil survey dilakukan menggunakan web mobile dengan kriteria penilaian dari BKKBN. Untuk mendapatkan data hasil survei secara cepat dan akurat, desa kutawaringin membutuhkan sebuah sistem penilaian yang efektif dengan penggunaan waktu seefisien mungkin. Karena itu di usulkan sebuah rancangan sistem penunjang keputusan penentuan kualitas kesejahteraan masyarakat di desa Kutawaringin menggunakan web mobile.

\section{B. Rumusan Masalah}

Berdasarkan latar belakang dapat di identifikasi beberapa masalah yaitu :

a. Bagaimana membuat sebuah sistem penunjang keputusan yang dapat membantu desa dalam menentukan kualitas kesejahteraan warganya menggunakan web

b. Bagaimana caranya untuk melakukan perhitungan hasil survei secara cepat dan akurat

c. Bagaimana caranya melakukan perhitungan hasil survei dengan penggunaan waktu seefisien mungkin agar di dapatkan keputusan hasil survei secara langsung.

\section{Tujuan Penelitian}

Tujuan dan manfaat dibangunya system pendukung keputusan berbais web mobile ini adalah :

a. Merancang sistem penunjang keputusan kualitas kesejahteraan masyarakat di desa Kutawaringin yang berbasis web

b. Membuat rancangan sistem yang akan membuat perhitungan hasil survei lebih cepat dan akurat sehingga pengambilan keputusan akan langsung di dapat setelah penginputan data selesai

c. Dengan dilakukannya penelitian ini diharapkan Desa Kutawaringin akan memiliki sistem penunjang keputusan berbasis web yang dapat mempermudah penentuan kualitas kesejahteraan warganya.

\section{LANDASAN TEORI}

\section{Sistem Penunjang Keputusan (SPK)}

Sistem penunjang keputusan merupakan sistem berbasis komputer yang diharapkan dapat membantu menyelesaikan masalah-masalah yang komplek yang tidak terstruktur maupun yang semi terstruktur. Sistem Penunjang Keputusan merupakan perpaduan antara keahlian manusia dan juga komputer. Dengan kemampuan yang dimiliki, sistem penunjang keputusan diharapkan dapat membantu dalam pengambilan keputusan baik untuk masalah semi terstruktur maupun tidak terstruktur (Turban dalam wulandari, 2013). Tujuan dari pembuatan Sistem Penunjang Keputusan yaitu (Turban dalam wulandari, 2013) :

a. Membantu manajer membuat keputusan untuk memecahkan masalah yang sepenuhnya terstruktur dan tidak terstruktur.

b. Mendukung penilaian manajer bukan mencoba menggantikannya. SPK tidak dimaksudkan untuk menggantikan manajer. Komputer dapat diterapkan dalam menyelesaikan masalah yang terstruktur. Untuk masalah yang tidak terstruktur, manajer bertanggung jawab untuk menerapkan penilaian, dan melakukan analisis.

c. Meningkatkan efektivitas pengambilan keputusan manajer daripada efisiennya. Tujuan utama SPK bukanlah untuk membuat proses pengambilan keputusan seefisien mungkin, tetapi seefektif mungkin.

\section{JQuery Mobile Framework}

Menurut Usada E. dkk (2013) Jquery Mobile adalah framework yang dibangun di atas jQuery yang menyediakan berbagai elemen User-interface dan fitur-fitur untuk digunakan dalam aplikasi mobile. Jquery mobile menunjukkan beberapa contoh bagaimana framework baru ini dapat membantu membangun aplikasi mobile berkualitas dan dalam waktu singkat. jQuery Mobile juga memastikan bahwa user-interface bekerja pada web browser dan menggunakan theme untuk memudahkan costumized tampilan aplikasi.

Dengan menggunakan jQuery Mobile, kita bisa membuat aplikasi web yang multiplatform, tidak tergantung pada piranti keras tertentu. Dengan kode yang sama, aplikasi web kita bisa jalan dihampir semua prianti mobile yang populer saat ini. Framework ini juga telah mendukung penggunaan layar sentuh, sehingga aplikasi kita bisa mengoptimalkan piranti yang ada (W. Edy dan Z. Ali, dalam Yusup M. dkk 2012)

\section{Kesejahteraan}

Sen dalam Umajah (2013) mengatakan bahwa welfare economics merupakan suatu proses rasional ke arah melepaskan masyarakat dari hambatan untuk memperoleh kemajuan. Kesejahteraan sosial dapat diukur dari ukuran- 
ukuran seperti tingkat kehidupan (levels of living), pemenuhan kebutuhan pokok (basic needs fulfillment), kualitas hidup (quality of life) dan pembangunan manusia (human development). Nicholson dalam Umajah (2013) mengemukakan prinsipnya mengenai kesejahteraan sosial; yaitu keadaan kesejahteraan sosial maksimum tercapai bila tidak ada seorangpun yang dirugikan.

BKKBN menerapkan ukuran kemiskinan dengan pendekatan kesejahteraan. Keluarga dapat dibagi dalam beberapa kategori: prasejahtera, sejahtera I, sejahtera II, sejahtera III, dan sejahtera III plus. Keluarga di kategorikan dalam tahap Prasejahtera apabila tidak dapat memenuhi salah satu syarat dari keluarga sejahtera tahap 1. Menurut BKKBN dalam Umajah (2013), Kesejahteraan keluarga digolongkan kedalam 3 golongan yang masing-masing mempunyai indikator yang tertulis dibawah dengan indikator ditulis secara berkelanjutan dari point a sampai w:

Keluarga Sejahtera Tahap I dengan kriteria sebagai berikut :

a. Anggota keluarga melaksanakan ibadah agama

b. Pada umumnya anggota keluarga makan 2 kali sehari atau lebih.

c. Anggota keluarga memiliki pakaian berbeda dirumah / pergi/bekerja / sekolah.

d. Bagian lantai yang terluas bukan dari tanah.

e. Anak sakit ataupun pasangan usia subur (PUS) yang ingin ber KB dibawa kesarana kesehatan.

Keluarga Sejahtera Tahap II, meliputi :

a. Anggota keluarga melaksanakan ibadah agama secara teratur

b. Paling kurang sekali seminggu lauk daging / ikan / telur

c. Setahun terakhir anggota keluarga menerima satu stel pakaian baru

d. Luas lantai paling kurang $8 \mathrm{~m} 2$ untuk tiap penghuni

e. Tiga bulan terakhir anggota keluarga dalam keadaan sehat dan dapat melaksanakan tugas

f. Ada anggota keluarga umur 15 tahun keatas berpenghasilan tetap.

g. Anggota keluarga umur $10-60$ th. bisa baca tulis latin

h. Anak umur $7-15$ th. Bersekolah

i. PUS dengan anak hidup 2 atau lebih saat ini memakai alat kontrasepsi

Keluarga Sejahtera Tahap III, meliputi :

a. Keluarga berupaya meningkatkan pengetahuan agama

b. Sebagian penghasilan keluarga ditabung

c. Keluarga makan bersama paling kurang sekali sehari untuk berkomunikasi

d. Keluarga sering ikut dalam kegiatan mesyarakat dilingkungan tempat tinggal.

e. Keluarga rekreasi bersama paling kurang sekali dalam enam bulan.

f. Keluarga memperoleh berita dari surat kabar/majalah/TV/radio.

g. Anggota keluarga menggunakan sarana transportasi setempat.

Keluarga Sejahtera Tahap III Plus, meliputi :

a. Keluarga secara teratur memberikan sumbangan

b. Ada anggota keluarga yang aktif sebagai pengurus yayasan / institusi masyarakat

Proses penilaian nya adalah dengan memberikan nilai pada setiap indikator seperti pada tabel berikut 
Tabel 1. Nilai dari setiap indikator

\begin{tabular}{|c|c|c|}
\hline $\mathrm{No}$ & indikator & Nilai $\left(n_{i}\right)$ \\
\hline 1 & $a$ & 1 \\
\hline 2 & $b$ & 1 \\
\hline 3 & $\mathrm{C}$ & 1 \\
\hline 4 & $\mathrm{~d}$ & 1 \\
\hline 5 & $\mathrm{e}$ & 1 \\
\hline 6 & $f$ & 1 \\
\hline 7 & g & 1 \\
\hline 8 & $\mathrm{~h}$ & 1 \\
\hline 9 & $\mathrm{i}$ & 1 \\
\hline 10 & $\mathrm{j}$ & 1 \\
\hline 11 & $\mathrm{k}$ & 1 \\
\hline 12 & 1 & 1 \\
\hline 13 & $\mathrm{~m}$ & 1 \\
\hline 14 & $\mathrm{n}$ & 1 \\
\hline 15 & 0 & 1 \\
\hline 16 & $p$ & 1 \\
\hline 17 & $q$ & 1 \\
\hline 18 & $r$ & 1 \\
\hline 19 & $\mathrm{~s}$ & 1 \\
\hline 20 & $\mathrm{t}$ & 1 \\
\hline 21 & $\mathrm{u}$ & 1 \\
\hline 22 & $\mathrm{~V}$ & 1 \\
\hline 23 & W & 1 \\
\hline \multicolumn{2}{|c|}{ Total (tot) } & 23 \\
\hline
\end{tabular}

Hitung total nilai dengan persamaan :

$$
t_{\text {ot }}=\sum n_{i}
$$

dimana:

tot : total nilai

$\sum n_{\mathrm{i}} \quad$ : jumlah nilai dari seluruh indikator.

Tingkat kesejahteraan diukur berdasarkan nilai dan indikator yang telah ditetapkan oleh BKKBN. Untuk menentukan tingkat kesejahteraan dilakukan berdasarkan total nilai yang didapat seperti pada tabel berikut.

Tabel 2. Tingkat kesejahteraan berdasarkan nilai

\begin{tabular}{|l|l|l|}
\hline No & kesejahteraan & nilai \\
\hline 1 & Prasejahtera & $<5$ \\
\hline 2 & Sejahtera I & $5-13$ \\
\hline 3 & Sejahtera II & $14-20$ \\
\hline 4 & Sejahtera III & $21-22$ \\
\hline 5 & Sejahtera III Plus & 23 \\
\hline
\end{tabular}

Contoh proses perhitungan nilai menggunakan script java sebagai berikut :

$$
<\text { html }><\text { script type="text/javascript" }>
$$

var tot $=24$;

var $\mathrm{sj}=$ "nilai tak terdaftar";

if(tot<5)\{sj="prasejahtera";

else $\{$ if $($ tot $<14)\{$ sj="sejahtera I"; $\}$

else $\{$ if(tot<21) $\{$ sj="sejahtera II"; $\}$

else $\{$ if $($ tot $<23)\{$ sj="sejahtera III"; $\}$

;\};\};;;\};

else $\{$ if $($ tot<24) $\{$ sj="sejahtera III Plus"; $\}$

alert (sj);

$<$ script $>$

$</$ html $>$ 


\section{METODE PENELITIAN}

Tahap Pengumpulan Data

1. Observasi Metode ini dilakukan dengan mendatangi langsung lokasi tempat penelitian untuk melihat kondisi ekonomi, sosial, dan budaya masyarakat untuk mendapatkan data penunjang yang mendukung penelitian.

2. Wawancara Metode ini dilakukan dengan mendatangi perangkat desa yang berwenang dalam tata admininstrasi desa Kutawaringin untuk mendapatkan data-data yang berhubungan dengan program kerja pembangunan desa sebagai referensi dan untuk mengetahui kebutuhan sistem yang akan di buat.

3. Pustaka Metode ini dilakukan untuk mendapatkan teori-teori para ahli tentang SPK, Jquery Mobile Framework, Dan kesejahteraan, sebagai pedoman dalam perancangan dan implementasi program.

Tahapan Pengaembangan Sistem

Dalam pengembangan Aplikasi ini menggunakan Sistem yang di rancang ini menggunakan metode Linear Sequential Model, model ini adalah melakukan pendekatan secara sistematis dan urut mulai dari level kebutuhan sistem lalu menuju ke tahap analisis, desain, coding, testing / verification, dan maintenance. Disebut dengan waterfall karena tahap demi tahap yang dilalui harus menunggu selesainya tahap sebelumnya dan berjalan berurutan[12].

\section{PERANCANGan dAN IMPLEMENTASI}

\section{A. Spesifikasi Hardware atau Software}

Untuk kelancaran pembuatan aplikasi penelitian ini menggunakan perangkat laptop ACER dengan spesifikasi sebagai berikut:

a. Hardware

1) Processor Intel ${ }^{\circledR}$ Pentium ${ }^{\circledR} P 6200$

2) Monitor 14.0" HD LED LCD

3) 1 GB DDR3 Memory

4) $320 \mathrm{~GB} H \mathrm{HD}$

5) 6-cell Li-ion battery

b. Software

1) Sistem operasi Windows 7

2) Microsoft Office 2007

3) Macromedia Dreamweaver 8

4) XAMPP Control Panel Version 2.5

5) Opera mobile web emulator

\section{B. Perancangan Sistem}

C. Diagram Konteks

Diagram konteks mencoba untuk memberikan gambaran arus sistem secara keseluruhan. 


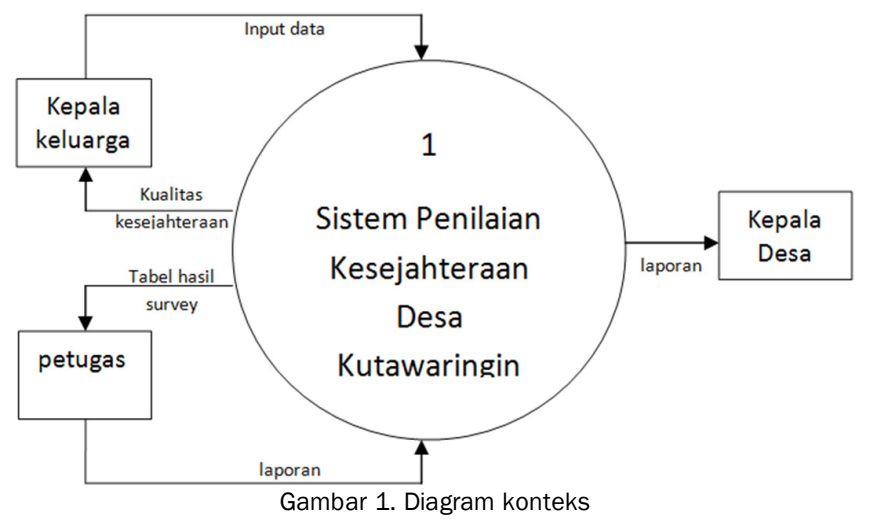

Dalam diagram konteks diatas terdapat 3 entitas luar yaitu kepala keluarga, petugas, kepala desa, dan sebuah proses yaitu proses penilaian kesejahteraan desa kutawaringin

D. DFD 0

DFD level 0 merupakan penjelasan lebih rinci dari diagram konteks.

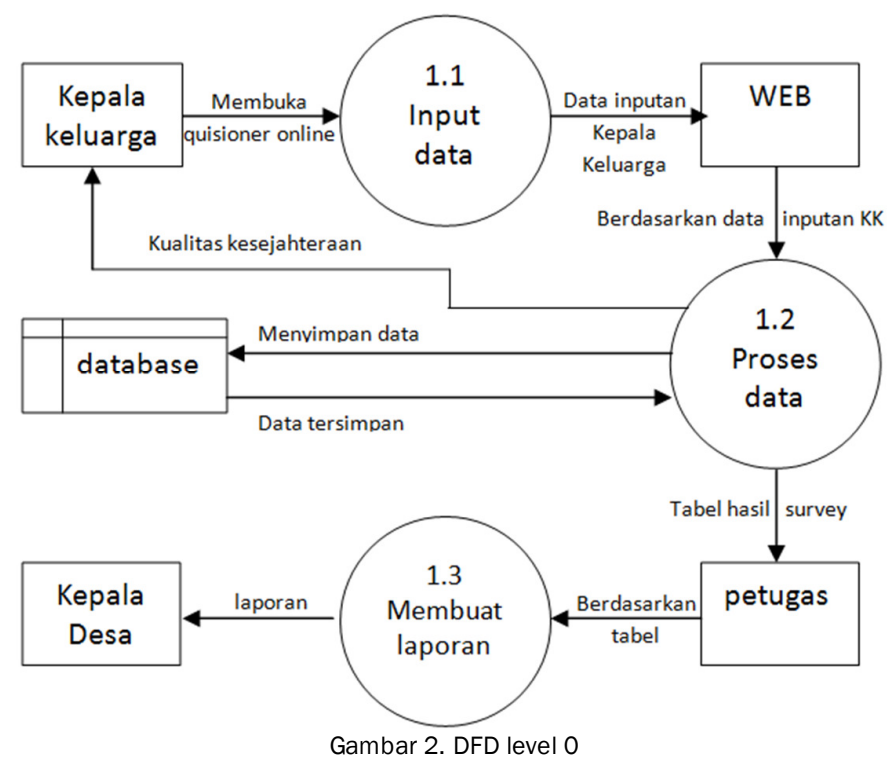

E. $E R D$

ERD menggambarkan hubungan relasi antar tabel dalam database.

\begin{tabular}{|c|c|c|c|}
\hline \multicolumn{2}{|r|}{ Survey } & \multicolumn{2}{|r|}{ keluarga } \\
\hline PK & ID Survey & PK & ID keluarga \\
\hline FK & $\begin{array}{l}\text { ID Keluarga } \\
\text { tanggal } \\
\text { Indikator a-w } \\
\text { nilai } \\
\text { kualitas }\end{array}$ & & $\begin{array}{l}\text { Kepala Keluarga } \\
\text { RT } \\
\text { RW }\end{array}$ \\
\hline
\end{tabular}

Gambar 4. Relasi antara tabel survey dan tabel keluarga 


\section{F. Implementasi}

Merupakan tahapan dimana hasil perancangan sistem dalam penelitian diterapkan kedalam sebuah sistem jadi yaitu web. Web yang di buat berisi beberapa modul yaitu:

a. Index.php

Merupakan halaman yang akan pertamakali di tampilkan ketika pengunjung membuka situs web.

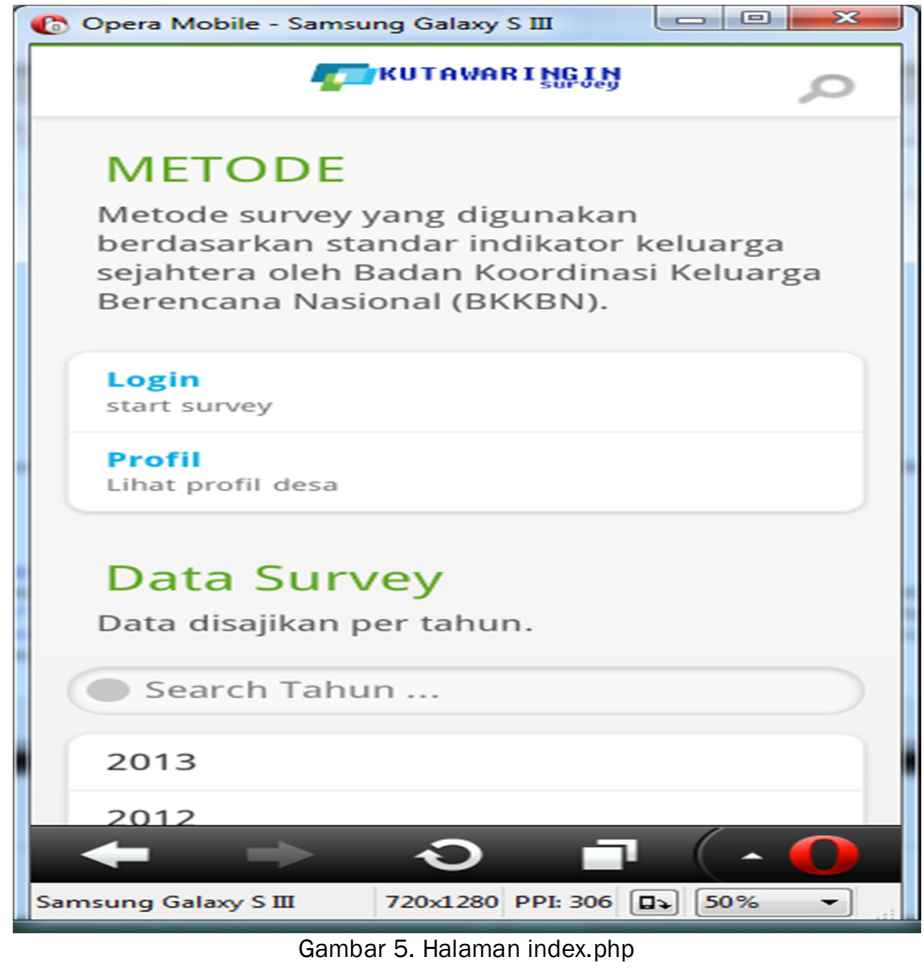

b. Tampil.php

Halaman ini akan menampilkan data-data hasil survey yang diperuntukan untuk publik dalam bentuk tabel.

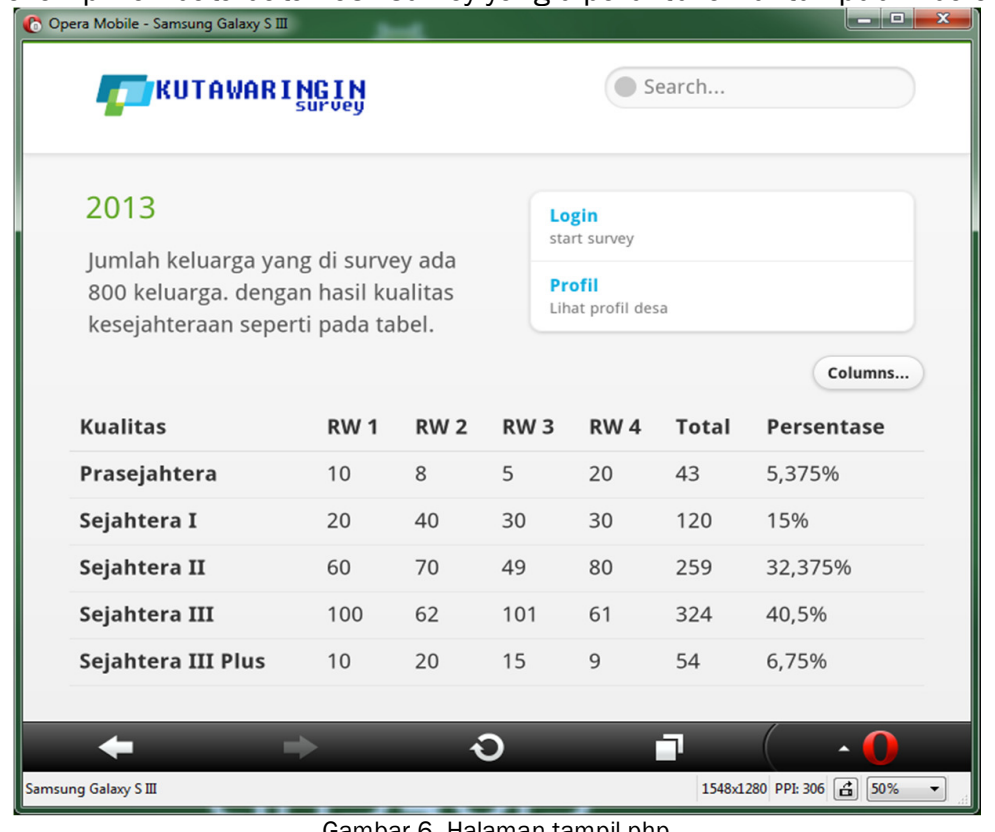

Gambar 6. Halaman tampil.php 
c. Login.php

Halaman ini diperuntukan untuk petugas survey yang akan melakukan input data. Petugas akan diminta untuk menginputkan Username dan password yang telah di tetapkan untuk dapat mengakses form quisioner dan melakukan penyetelan.

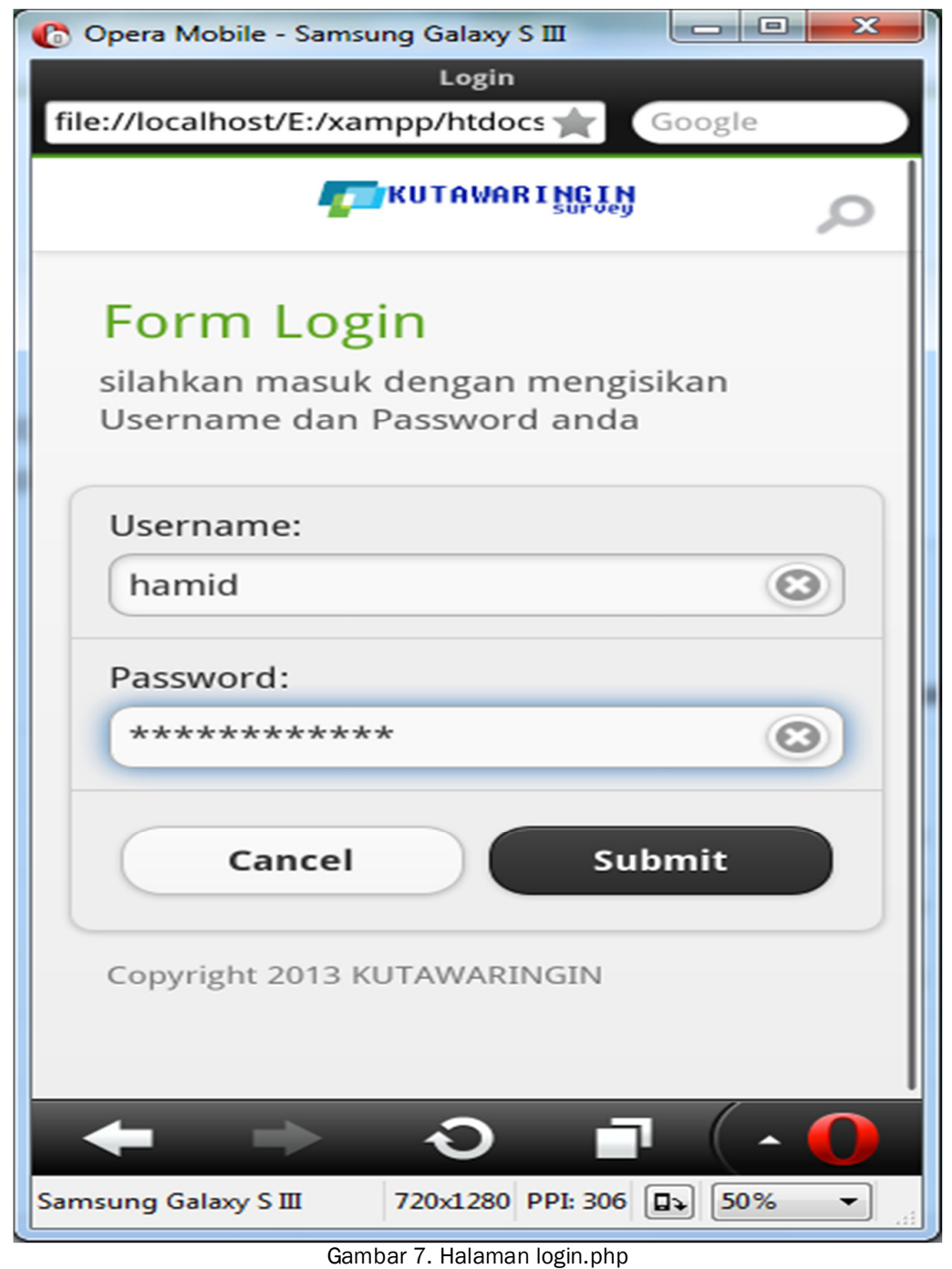

d. Quisioner.php

Menampilkan form input data yang akan di isi oleh petugas survey untuk selanjutnya data akan di simpan kedalam database. 


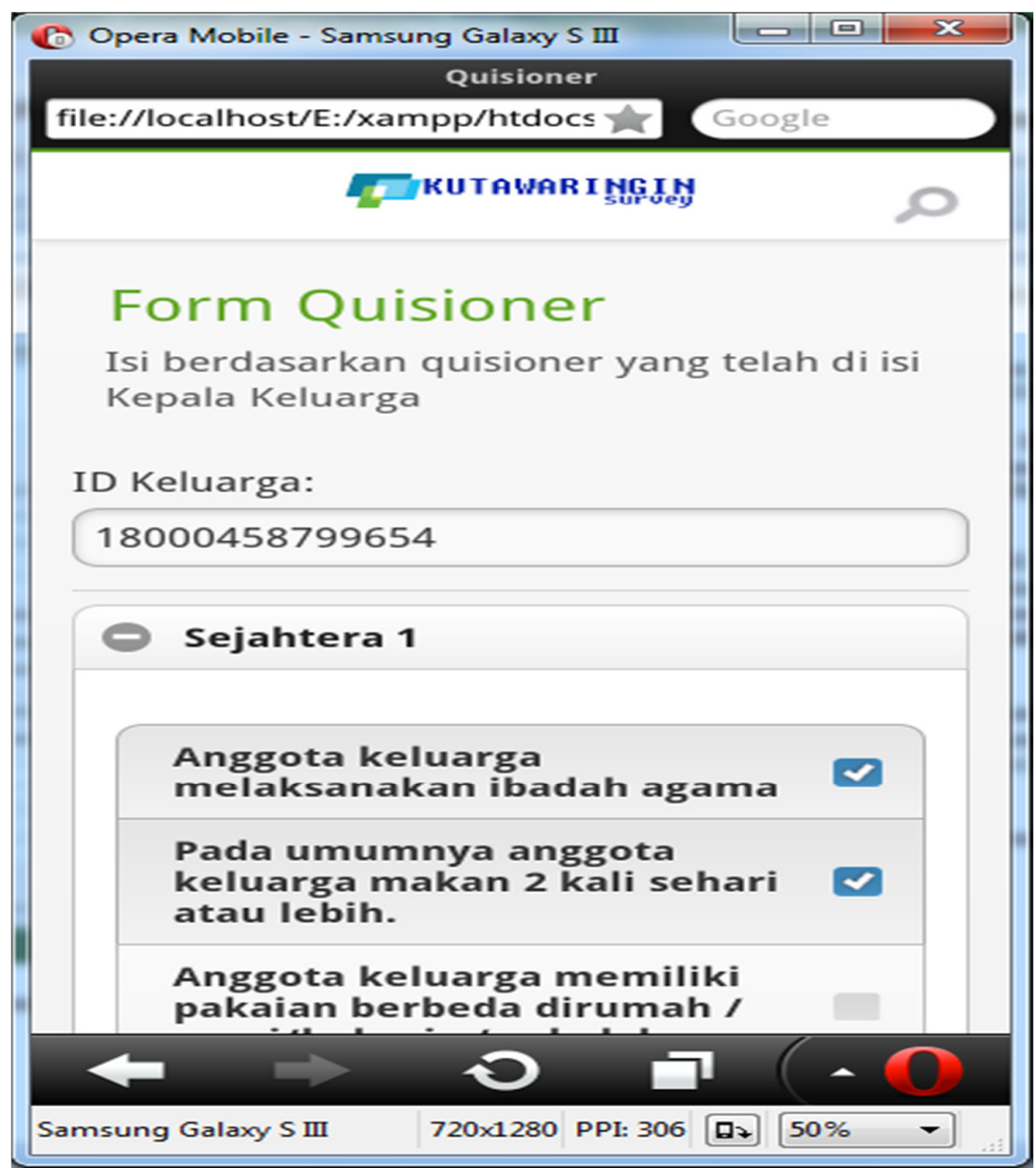

Gambar 7. Halaman quisioner.php

\section{KESIMPULAN}

Dari hasil penelitian dapat ditarik beberapa kesimpulan :

a. Sistem Penunjang Keputusan dengan menggunakan web membantu desa dalam menentukan kualitas kesejahteraan warganya

b. Penggunaan aplikasi web membuat Perhitungan hasil survei lebih cepat, akurat serta akses yang mudah tanpa dibatasi jarak dan waktu.

c. Dari hasil uji testing yang dilakukan kepada 800 data penduduk yang di survai didapatkan hasil 43 orang digolongkan prasejahtera, 120 orang sejahtera satu, 259 orang sejahtera dua, 324 orang sejahtera tiga dan 54 orang tergolong sejahtera 3 tiga plus.

\section{REFERENSI}

[1] Andi Maslan, Yana Setiono, Faizal Alfazri, 2016. Pengembangan Smart Application Translation Bahasa Sulawesi Berbasis Android. TEKNOSI, Vol. 02, No. 01, April 2016. Hal. 55-64. Universitas Andalas. Sumatra Barat.

[2] Yusup M., Warsito A.B. 2012. Pengembangan Sistem Penerimaan Mahasiswa (Sinema) Berbasis Web Mobile Pada Perguruan Tinggi Raharja. STMIK Raharja Tangerang. Desember 2012

[3] Sri Redjeki, M.Guntara, Pius Anggoro. 2014. Perancangan Sistem Identifikasi dan Pemetaan Potensi Kemiskinan untuk Optimalisasi Program Kemiskinan. Jurnal Sistem Informasi (JSI), VOL. 6, NO. 2,Oktober 2014, Hal 731-734.Unsri.Palembang

[4] Sunarti, Euis. 2006. Indikator Keluarga Sejahtera Sejarah Pengembangan, Evaluasi dan Keberlanjutanya. Fakultas Ekologi Manusia IPB. Bandung. 
[5] Sugiharto E, Salmani, Gunawan BI. 2013. Studi Tingkat Kesejahteraan Masyarakat Nelayan Di Kampung Gurimbang Kecamatan Sambaliung Kabupaten Berau (Study on welfare level of fishing community at Gurimbang Village, Sambaliung Subdistrict of Berau). Jurnal IImu Perikanan Tropis Vol. 18. No. 2, April 2013. Hal 68-74. Universitas Mulawarman. Samarinda.

[6] Redaksi. 2010. Kriteria Dan Batasan Orang Miskin di Indonesia.http://gemaniasbarat.wordpress.com/2010/01/17/kriteria-dan-batasan-orangmiskin-di-indonesia/ (01-12-2013, 10.07 am)

[7] Rencana Kerja Pembangunan Pekon (RKPP) Desa Kutawaringin Tahun Anggaran 2013

[8] Sugiharto E. 2007. Tingkat Kesejahteraan Masyarakat Nelayan Desa Benua Baru Ilir Berdasarkan Indikator Badan Pusat Statistik. EPP.Vol.4. No.2. Tahun 2007:32-36

[9] Usada E. dkk. 2013. Rancang Bangun Sistem Informasi Jadwal Perkuliahan Berbasis JQuery Mobile Dengan Menggunakan PHP Dan MySql. Akademi Teknik Telekomunikasi Sandhy Putra Purwokerto

[10] Wulandari, Prihayati. 2013. Sistem Penunjang Keputusan Pemilihan Metode Alat Kontrasepsi. Program Magister Keperawatan Maternitas Universitas Indonesia

[11] www.damandiri.or.id/file/sitiumajahmasjkuriunairbab2.pd... (1 Nov 2013) 